\title{
TEMPERATURE PROFILES FOR THE BARNES ICE GAP SURGE ZONE
}

\author{
By D. F. CLASSEN \\ (Department of Physics, University of Victoria, Victoria, British Columbia V8W2 Y2, Canada)
}

\begin{abstract}
Thermal drilling and deep ice-temperature measurements along a flow line in a surge area of the Barnes Ice Cap, Baffin Island, N.W.T., Canada revealed a layer of basal temperate ice $30 \mathrm{~m}$ thick. $\mu \mathrm{cal} / \mathrm{cm}^{2} \mathrm{~s}\left(4^{2} \mathrm{~mW} / \mathrm{m}^{2}\right)$.

RÉsumé. Profils de température pour la zone de crue de la calotte de Barnes. Des sondages thermiques et des mesures de températures de la glace en profondeur le long de la ligne d'écoulement dans la zone de crue base de glace tempérée de $30 \mathrm{~m}$ d'épaisseur. Baffin, T.N.-O., Canada, ont révélé l'existence d'un niveau de flux géothermique est estimé à $\mathrm{r}, 02 \mu \mathrm{cal} / \mathrm{cm}^{2} \mathrm{~s}\left(42 \mathrm{~mW} / \mathrm{m}^{2}\right)$ latérales, la glace était froide jusqu'au lit et le

Zusammenfassunc. Temperahr-Profile in $\left(42 \mathrm{~mW} / \mathrm{m}^{2}\right)$

und Temperaturmessungen im tiefen Eis in der Ausbruchszone der Barnes-Eiskalotte. Thermische Bohrungen Baffin Island, N.W.T., Kanada, erwiesen längs einer Stromlinie im Ausbruchsgebiet der Barnes-Eiskalotte, Mächtigkeit. Für Randgebiete konnte ein Anfrieren am Untergrund Eises über dem Untergrund mit $30 \mathrm{~m}$ Wärmestrom liess sich $\mathrm{zu} \mathrm{I}, 02 \mu \mathrm{cal} / \mathrm{cm}^{2}\left(42 \mathrm{~mW} / \mathrm{m}^{2}\right)$ abschätzen.
\end{abstract}

\section{INTRODUGTION}

The Barnes Ice Cap is a medium-sized, predominantly sub-polar ice cap of approximately $600 \mathrm{~km}^{2}$ located in the highland area of north-central Baffin Island, Northwest Territories, Canada (Fig. I). Sighted from a distance during an expedition led by Wordie to Melville Bay and north-east Baffin Land in I934, it has become the subject of a series of glaciological studies beginning in r950 (Goldthwait, r95 I ; Baird, r952; Ward, I952 [a], [b]; Ward and Orvig, I953; Orvig, I953; Littlewood, 1952) and continuing until the present day. The ice cap, previously thought to be a relic from before the post-glacial climatic optimum, is unusual in that its nourishment is by the formation of superimposed ice rather than snow-firn-ice metamorphosis. Recent evidence (Hooke, r 976) indicates that the ice cap may be sitting on
Pleistocene ice.

Recent research interests have shifted from a general overview of the ice cap and, during the years 1966-75, a great deal of effort was expended to identify, substantiate, describe, and parameterize various features of the ice cap including, of particular interest, a surge zone and its surrounding area on the south dome's south-east lobe (Løken and Andrews, I966; Clough and Løken, I968; Løken and Sagar, r 968; Løken and others, r968; Løken, r969; Barnett and others, I970; Holdsworth, I973[a], [b]; Hooke, r973[a], [b]; Barnett and Holdsworth,
r974).

Preliminary evidence for two surges on the Barnes Ice Cap is given by Løken (1969). A closer examination has been made and additional independent evidence is convincingly presented by Holdsworth (1973[a]) for the surge area on the south-east lobe of the south dome. This evidence consists collectively of ice-surface morphology; marginal-moraine geometry and chronology; basal conditions as determined from flow-rate, ice-depth, and shallowtemperature data; and geological-hydrological observations. It has been determined that the surge could have occurred as recently as 1927 and the possibility of multiple surging is not
to be disregarded.

Measurements done in I966 indicated that basal sliding velocities of up to $22.5 \mathrm{~m} \mathrm{a}^{-1}$ exist close to the flow-line os of Holdsworth (I973[a]) and that basal temperatures might range from the pressure-melting point at the central core of the dome to sub-freezing at the
margin. 


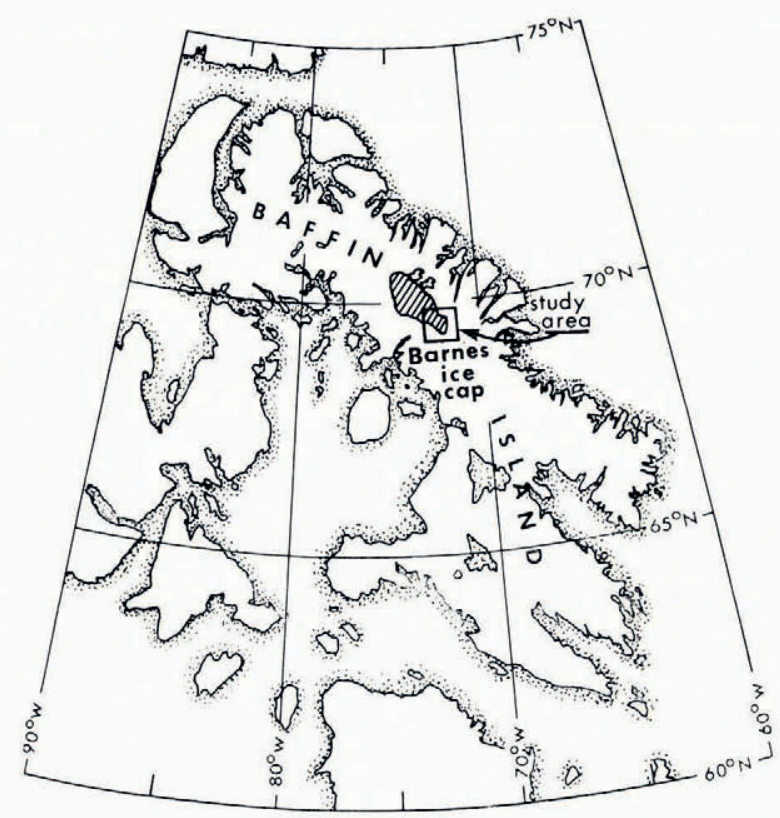

Fig. I. Map of Baffin Island showing location of study area.

This paper concerns temperature measurements made by the author in an effort to develop further a surge theory for the Barnes Ice Cap and perhaps reveal the initiation mechanism responsible. Temperature profiles were obtained at three locations of interest along a central flow-line of the surge area using thermal drilling and resistance temperaturemeasurement techniques. Results indicated that basal temperate ice, that is, ice at the pressure-melting point, was present in the central region and that extensive fringe areas were frozen at the base.

\section{ExPERIMENTAL METHODS}

\section{Thermistors and measuring equipment}

Temperature measurements were made with Yellow Springs Instrument Company 44004 and 44033 Precision Thermistors with a nominal resistance of $225^{2} \Omega$ at $25^{\circ} \mathrm{C}$ and a Data Precision Model 245 digital multimeter for reading thermistor resistances.

\section{Thermistor preparation and use}

Seventy-five thermistors were calibrated in a Colora KT $20 \mathrm{~S}$ constant-temperature bath at five points between approximately $-13.0^{\circ} \mathrm{C}$ and $0.0^{\circ} \mathrm{C}$. A stainless-steel thermistor needle-probe, calibrated by the National Research Council to its own specifications at eleven points, was used as a standard. A table of resistance values for this standard was computed over the range $-10.0^{\circ} \mathrm{C}$ to $40.0^{\circ} \mathrm{C}$ at $0.1 \mathrm{deg}$ intervals by fitting the calibration data to a curve

$$
\mathrm{I} / \mathcal{T}=A+B\left(\ln R_{\mathrm{T}}\right)+C\left(\ln R_{\mathrm{T}}\right)^{3},
$$

where $T$ is the absolute temperature and $A, B$ and $C$ constants. The heating effect due to test current flow was $0.3^{8} \mathrm{~mW} / \mathrm{deg}(2642 \mathrm{deg} / \mathrm{W})$ and was extrapolated to zero current, 
that is, no self-heating. Linear interpolation by the author between points gave o.or deg increment values.

Batches of twenty-two thermistors were placed in a water-filled, copper cylinder of $\mathrm{I}$ in. $(2.54 \mathrm{~cm})$ diameter along with the standard thermistor. The cylinder was then placed in the circulating control solution of $30 \%$ methanol- $70 \%$ water and the thermistor resistances read after an equilibrium temperature had been established in the ice medium which formed in the cylinder. The control solution temperature was maintained to better than $\pm 0.0 \mathrm{I}$ deg during the calibration.

Resistances were read with a Data Precision Model 245 digital multimeter. The test current in the measuring circuit (10 $\mathrm{k} \Omega$ scale) was $0.330 \mathrm{~mA}$, a value which caused all of the thermistors, including the standard, to self-heat. As a result the resistance values of the standard represented colder ambient temperatures than the NRG calibration tables indicated. A correction determined from the equation

$$
P=E_{\mathrm{T}} I_{\mathrm{T}}=I_{\mathrm{T}^{2}} R_{\mathrm{T}}=\delta\left(T-T_{\mathrm{a}}\right),
$$

where $E_{\mathrm{T}}$ and $I_{\mathrm{T}}$ are the steady-state or static thermistor voltage and current, $\delta$ is the dissipation constant of the thermistor, $T_{\mathrm{a}}$ is the ambient temperature, and $T$ the body temperature of the thermistor, with $\delta_{\text {ice }}=2.0 \mathrm{~mW} / \mathrm{deg}$ was applied to each standard resistance-value which resulted in listings of true ambient temperature as a function of self-heated resistance for the calibrated thermistors. The computer program for reducing calibration data was kindly provided by A. Beck.

The dissipation constant for ice was determined experimentally by measuring the resistance of one of the thermistors using a Wheatstone bridge with approximately $30 \mu \mathrm{A}$ current. The difference in resistance values between the bridge and the meter, I I $2 \Omega$, was equivalent to $\Delta T=0.28 \mathrm{deg}$ since over the range 5 ooo $\Omega$ to 6 ooo $\Omega$ in which the values were contained the variation of resistance with temperature for the thermistors under consideration was $4 \Omega /$ o.o I deg. This coincided with the manufacturers' suggested value of $\delta_{\text {ice }}=2.0 \mathrm{~mW} / \mathrm{deg}$ which yielded $\Delta T=0.28 \mathrm{deg}$ from the above equation and served as a check on the correction method.

A detailed treatment of the theory and application of self-heated thermistors as well as the method of correcting values is presented by Sapoff and Oppenheim (1963) and it is strongly recommended that this paper be studied by applied glaciologists. For the experiment described in this paper, self-heating is not desirable; it was incurred, however, when it was discovered only shortly before departure that the digital-meter test-current was an order of magnitude larger than original calculations indicated and no time was available to obtain a more appropriate measuring system.

In the field, the thermistors were used in air since they were placed in what was believed to be a well-sealed air pocket along the cable. Therefore an air-equivalent calibration was necessary. This was achieved by applying the correction obtained using the above equation with $\delta_{\text {air }}=1.0 \mathrm{~mW} / \mathrm{deg}$ to the self-heated resistance values of the calibration.

The effects of the materials surrounding the air pocket on the value of the in situ dissipation constant has been assumed negligible. This includes the cable insulation, tape wrapping, and water or ice medium. Water or ice in the air pocket has been considered unlikely due to the extreme care taken to ensure that each section of the PVG cable was well wrapped with selfvulcanizing tape in the time-honored way. It is also possible that the thermistor may have been in partial contact with the cable interior. In all of these cases the effect would be influenced by the thermal resistance of these materials, but would in general tend toward slightly warmer temperatures than those presented in the data sets. An off-setting effect would be any remnant due to the temperatures representing only "near-equilibrium" conditions. The precise effect is unknown but it is not unreasonable to view these two effects as essentially cancelling each other. Although there are definite implications regarding an attempt to 
estimate the accuracy of the individual measurements, no damage is done to the more important conclusions drawn later in this paper and the macro-scale thermal regime of the area of concern is placed beyond doubt.

The error estimates shown on the data tables are the "most optimistic" values. The power dissipated in the thermistors can be fairly well determined; the poorly defined physical conditions (in terms of the dissipation constant) under which the thermistors are deployed and the extrapolation of results to zero reciprocal time, however, caution against strong claims of better than \pm 0.1 deg accuracy. This degree of accuracy is acceptable for any use to which the data are likely to be put.

Calibrated thermistors were placed at io $\mathrm{m}$ intervals (seven per cable) on multi-conductor cables. Thermistor-cable assemblies were attached to the thermal probe power-supply cables at $2 \mathrm{~m}$ intervals and allowed to freeze in place when the drilling was considered complete.

The method of calibrating thermistors and assembling the cables have been described in detail by Classen and Clarke (1972) and Jarvis (unpublished).

\section{Drilling procedures}

A drilling program was carried out during the period 17 April to 28 May 1975 at locations along the ss flow-line (Fig. 2) of the Barnes Ice Cap using a small thermal probe (Classen and

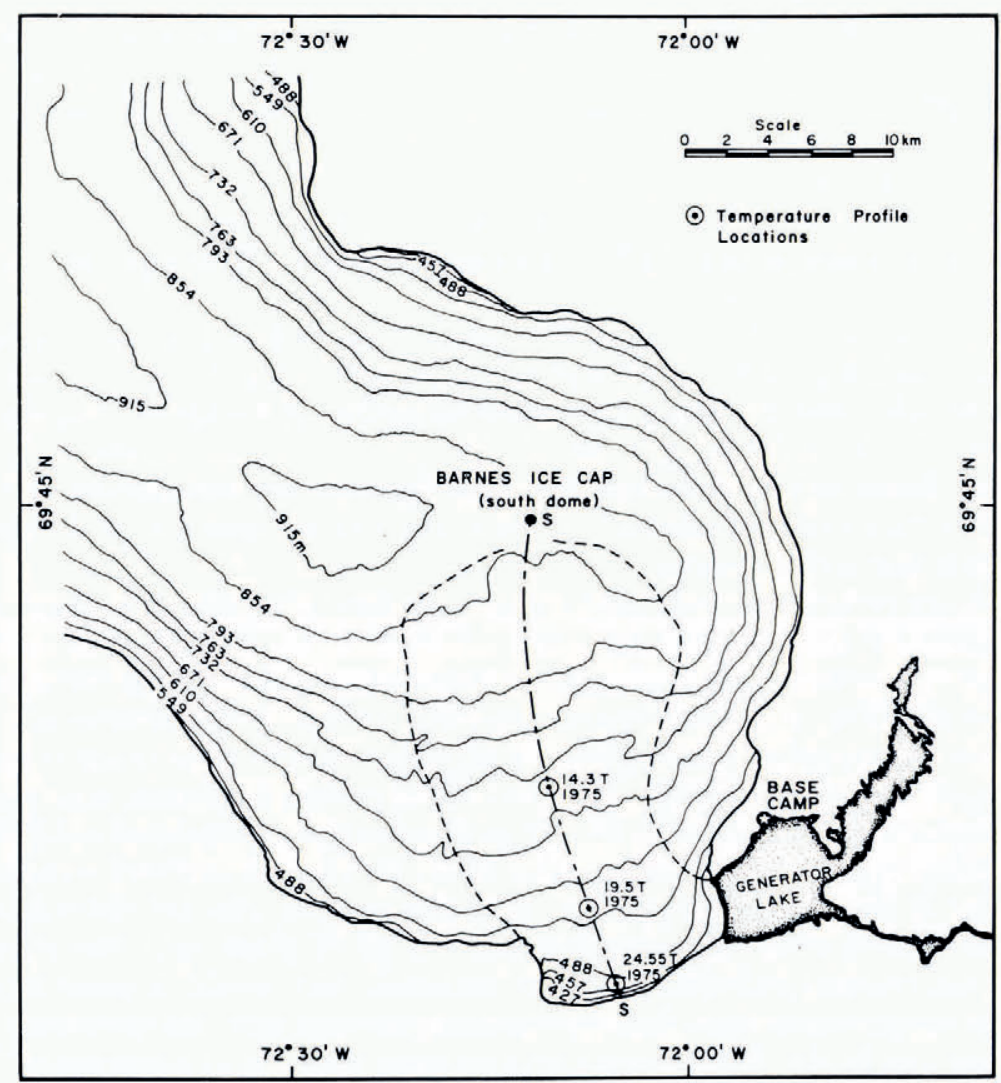

Fig. 2. South dome of the Barnes Ice Cap showing temperature-profile locations along the ss flow line and approximate outline (dashed) of the surge zone. 
Clarke, 1972) designed for sub-polar ice. The positions of these drilling sites in the surge area are shown in Figures 2 and 3. Seven attempts yielded three instrumented sites with depths of $200.0 \mathrm{~m}, 122.0 \mathrm{~m}$ and $88.0 \mathrm{~m}$ at positions $14.30 \mathrm{~km}, 19.50 \mathrm{~km}$ and $24.55 \mathrm{~km}$ along this line. The selected drilling sites correspond to points on the ice surface directly above regions thought on the basis of calculations by Holdsworth (1973[a]) to be at pressure-melting point, near pressure-melting point, and with substantially sub-freezing temperatures. A summary of drilling results with causes for termination is given in Table I. The drilled depths are compared with ice depths supplied by S. J. Jones (personal communication in 1975) as determined by radio depth-sounding techniques (Jones, 1972). Figure 3 presents the ss flow-line profile with the extent of temperature-profile coverage shown.

TAble I. Drilling Results for Barnes Ice Gap

\begin{tabular}{|c|c|c|c|c|c|c|}
\hline \multirow[t]{2}{*}{ Location } & \multirow[t]{2}{*}{ Reference* } & \multirow[t]{2}{*}{ Attempt } & \multirow[t]{2}{*}{ Date } & \multicolumn{2}{|c|}{ Depth } & \multirow{2}{*}{ Reason for termination } \\
\hline & & & & $\begin{array}{l}\text { Drilled } \\
\qquad \mathrm{m}\end{array}$ & $\begin{array}{l}\text { Radio-echo } \\
\text { sounding } \\
\mathbf{m}\end{array}$ & \\
\hline I 4.3 T 1975 & I $4.3 \mathrm{ss}$ & I $4 \cdot 30-6$ & I7 May 1975 & 200.0 & 220.0 & $\begin{array}{l}\text { Insufficient manpower at drill- } \\
\text { ing site to maintain workable } \\
\text { shift schedule over longer } \\
\text { period of time }\end{array}$ \\
\hline \multirow[t]{5}{*}{ I9.5 T 1975} & I $9.5 \mathrm{ss}$ & I9.50-I & I May 1975 & 10.0 & & $\begin{array}{l}\text { Freeze-in due to obstruction of } \\
\text { thermistor pod on edge of } \\
\text { drill hole }\end{array}$ \\
\hline & & I9.50-2 & I May r975 & 17.0 & & Short in power cable at plug \\
\hline & & $19 \cdot 5^{0-3}$ & 3 May 1975 & 40.0 & & $\begin{array}{l}\text { Short in power cable about } \\
10 \mathrm{~m} \text { from plug }\end{array}$ \\
\hline & & I9.50-4 & 7 May 1975 & 70.0 & & $\begin{array}{l}\text { Probe burn-out from circuit } \\
\text { overload due to increased } \\
\text { generator speed. Operator } \\
\text { error }\end{array}$ \\
\hline & & $19 \cdot 50-7$ & 21 May 1975 & 122.0 & 192.0 & $\begin{array}{l}\text { Sudden reduction in drilling } \\
\text { rate probably due to englacial } \\
\text { debris }\end{array}$ \\
\hline 24.55 т 1975 & $24.55 \mathrm{ss}$ & $24 \cdot 55-5$ & 8 May 1975 & 88.0 & I 15.0 & $\begin{array}{l}\text { Sudden reduction in drilling } \\
\text { rate probably due to en- } \\
\text { glacial debris }\end{array}$ \\
\hline
\end{tabular}

* Location on survey line ss. All holes are approximately $5 \mathrm{~m}$ west of respective survey poles.

The general procedures following the establishment of a fly-camp at the selected location included clearing away recent surface accumulation down to solid ice in order to prevent loose snow from falling into the drill hole. The probe was then connected to the generator and the thermistor cable taped to the probe power-supply cable as the probe descended. Hole closure due to refreezing of melt water in the hole prevented retrieval of the probe, and the entire instrument package was allowed to freeze in place once drilling had ceased and before temperature measurements were begun. Detailed descriptions of basic procedures and technical aspects including measuring procedures are presented by Classen (unpublished), Classen and Clarke (1972), and Jarvis (unpublished).

Minor modifications to the drilling equipment included soldering of the heating element into the copper tip as opposed to use of a thermal compound, insertion of the heating element to within 0.25 in. $(6 \mathrm{~mm})$ of the tip, increasing the probe length to $60 \mathrm{~cm}$, and employing a four-conductor power cable for varying line heating (Jarvis, unpublished).

Due to supply problems, I 8 gauge Beldon 8489 cable was substituted for the customary 16 gauge Beldon 8620 . This proved unsatisfactory for use in the high-line-heating mode due 


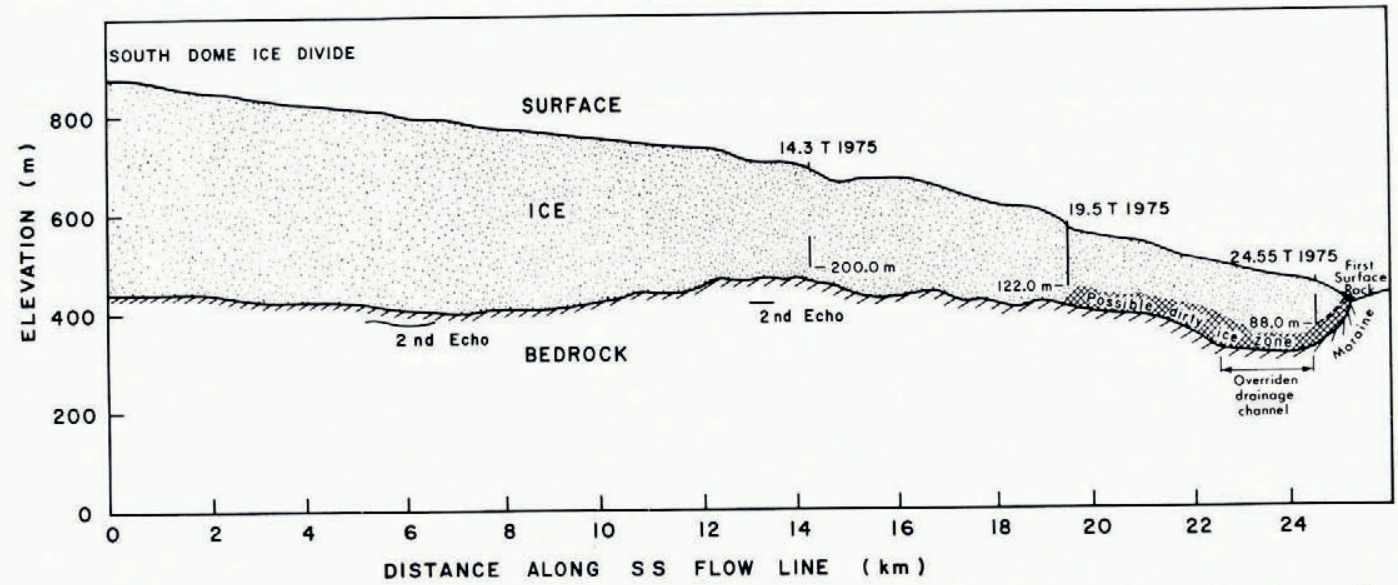

Fig. 3. Cross-section along ss flow line indicating temperature data coverage. Secondary reflections from radio-echo-sounding survey are included. Distribution of dirty ice is merely representational and should not be construed as mechanically correct. Vertical exaggeration is $\times I O$.

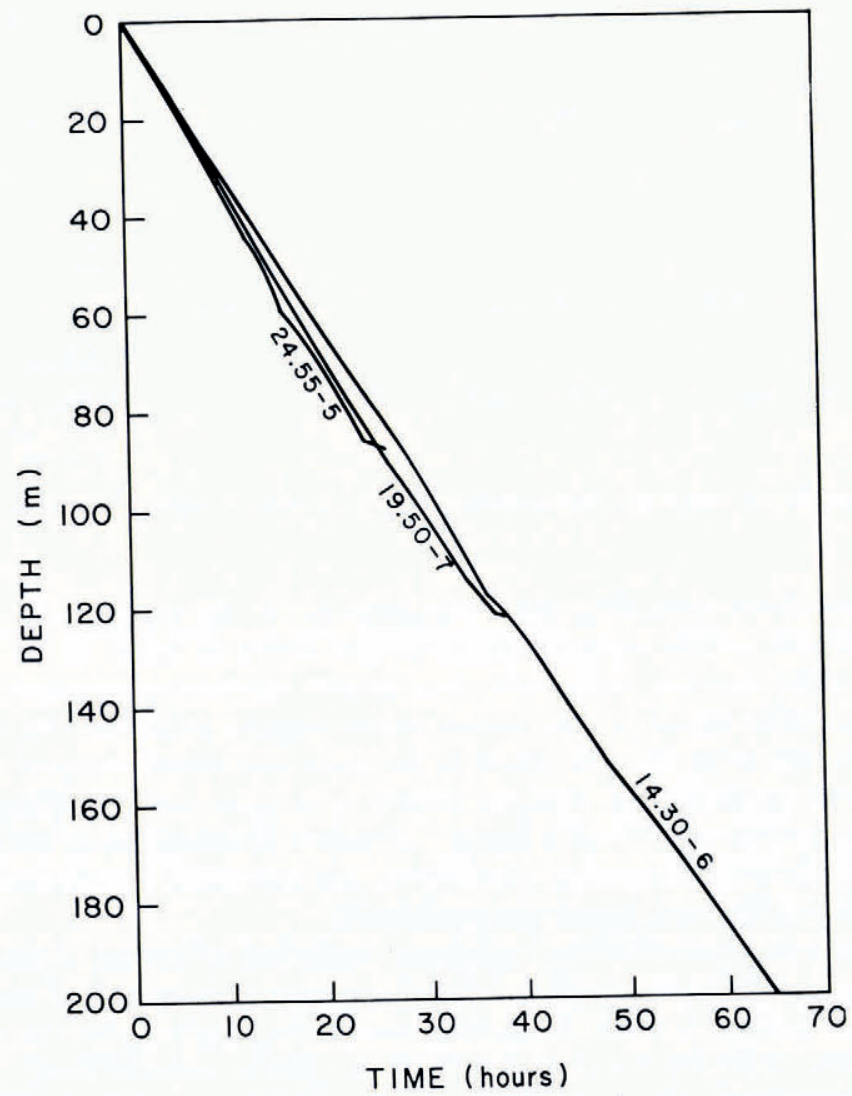

Fig. 4. Drilling log of holes $14 \cdot 30-6,19 \cdot 50-7$, and 24.55-5. Sudden decrease of drilling rate is thought to indicate englacial debris zones. 
to insulation failure and short-circuiting in the presence of high (20 A) current. It is thought that the same problem probably occurs with i 6 gauge cable but may have previously gone undetected or been misinterpreted. In addition, the PVC-jacket insulation was not suitable for the air temperatures encountered, which ranged between $-34.0^{\circ} \mathrm{C}$ and $-1.3^{\circ} \mathrm{C}$.

Resort was made to the use of low line heating for the majority of the program, despite which no side-wall freezing was experienced. Although the power output of the heating elements was $10.4 \%$ below manufacturer's specifications $(2240 \mathrm{~W}$ at the maximum $20 \mathrm{~A}$ current rather than the rated $2500 \mathrm{~W}$ ) drilling rates generally approached $4.0 \mathrm{~m} / \mathrm{h}$, seldom decreasing below $3.4 \mathrm{~m} / \mathrm{h}$ for the $7.6 \mathrm{~cm}$ diameter probe.

The depth of $200 \mathrm{~m}$ reached at station 14.30 is somewhat notable in that the design capabilities for this probe were exceeded for the first time by a substantial degree. Previous experience among the various persons involved with the probe indicated that nothing beyond about $125 \mathrm{~m}$ was feasible. There are a number of factors which may provide a partial explanation of this result. The heaters, though no more robust than in past applications, were in better thermal contact with the probe head. This was achieved by filling the heater cavity with solder before inserting the heater itself. Line heating, though employed, is generally not considered to be highly advantageous. Original design specifications assumed ice temperatures around $-8^{\circ} \mathrm{C}$ and some benefit was undoubtedly given by the generally lower temperatures of the medium. Additionally, and perhaps most importantly, the ice in this region is under a slightly extensional force field, and it is possible that the melt water may have partially or completely drained away through small fissures.

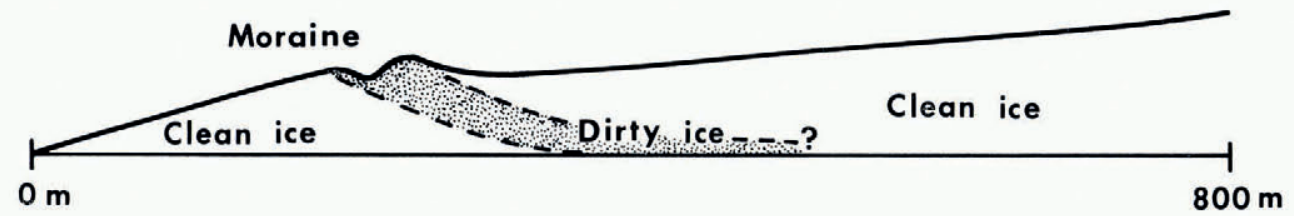

Fig. 5. Sketch of ice-cap margin showing moraine and inferred distribution of debris-bearing ice. After Hooke (1973[b]).

A drilling log for the three deepest attempts is presented in Figure 4. The sharp reduction of drilling rates for $24.55-5$ and $19.50-7$ are indicative of accumulating dirt or rock particles in the hole and thus an englacial-debris zone can be inferred. As no provisions were made for recovering cores or melt water, no further analysis was possible.

Hooke (1973[a]) refers to descriptions of ice-cored moraines at short distances up-glacier from the margin of an ice cap. These occur with no apparent supraglacial source of debris but with debris bands dipping steeply up glacier from beneath the ice (Fig. 5). Surface evidence of similar features has been observed along the margins as well. In view of this, it is not surprising that a dirty-ice zone was struck at $24.55 \mathrm{~km}$ at $88.0 \mathrm{~m}$ depth. At $19.50 \mathrm{~km}$, however, the possible presence of a debris zone produced by this mechanism does not seem as likely at the relatively more shallow $\mathbf{2 2} .0 \mathrm{~m}$ depth and this may have to be explained by appealing to some other process such as transport from the bed by inclusion in refrozen basal melt water or the surge itself.

Total hole depth was $547 \mathrm{~m}$. This required $156 \mathrm{~h}$ of drilling time and approximately I 50 gal $\left(34 \mathrm{~m}^{3}\right)$ of fuel. Man-hours in the field totalled 920 for the two-man crew and it is recommended that a three-man crew be utilized for any drilling attempts exceeding $120 \mathrm{~m}$.

\section{RESULTS}

Table II presents ice temperature and depth measurements for three locations on the Barnes Ice Cap where the depth to bedrock has been estimated by radio-echo sounding. 
Table II. Barnes Ige Gap temperature data

\begin{tabular}{cc}
\multicolumn{2}{c}{ I4.3 T 1975} \\
2 July 1975 \\
$\begin{array}{c}\text { Thermistor } \\
\text { depth }\end{array}$ & $\begin{array}{c}\text { Corrected ice } \\
\text { temperature }\end{array}$ \\
$\mathrm{m}$ & ${ }^{\circ} \mathrm{G}$ \\
140.0 & $-\mathrm{r} .50 \pm 0.02$ \\
150.0 & $-\mathrm{r} .16 \pm 0.01$ \\
160.0 & $-0.90 \pm 0.01$ \\
170.0 & $-0.66 \pm 0.02$ \\
180.0 & $-0.49 \pm 0.01$ \\
190.0 & $-0.13 \pm 0.04$ \\
200.0 & $-0.13 \pm 0.02$ \\
& \\
220.0 & Bottom
\end{tabular}

\begin{tabular}{|c|c|}
\hline $\begin{array}{c}\text { Thermistor } \\
\text { depth } \\
\mathrm{m}\end{array}$ & $\begin{array}{l}\text { Corrected ice } \\
\text { temperature } \\
{ }^{\circ} \mathrm{G}\end{array}$ \\
\hline 10.0 & $-9.95 \pm 0.02$ \\
\hline 17.0 & $-7.91 \pm 0.03$ \\
\hline 20.0 & $-7.3^{2} \pm 0.02$ \\
\hline 30.0 & $-6.06 \pm 0.03$ \\
\hline 40.0 & $-5.10 \pm 0.03$ \\
\hline 50.0 & $-4.27 \pm 0.02$ \\
\hline 60.0 & $-3.57 \pm 0.02$ \\
\hline 62.0 & $-3.50 \pm 0$ OI \\
\hline 70.0 & $-2.97 \pm 002$ \\
\hline 72.0 & $-2.90 \pm 0 \mathrm{OI}$ \\
\hline 82.0 & $-2.44 \pm 002$ \\
\hline 92.0 & $-\mathrm{r} .9^{8} \pm$ o or \\
\hline 102.0 & $-\mathrm{r} .60 \pm 0 \mathrm{or}$ \\
\hline I 12.0 & $-\mathrm{I} \cdot 37 \pm$ O OI \\
\hline I 22.0 & $-0.9^{2} \pm 002$ \\
\hline I 92.0 & Bottom \\
\hline
\end{tabular}

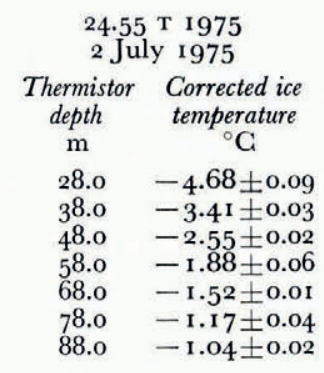

I 5 o Bottom

These results are shown graphically as vertical temperature profiles in Figures 6, 7, and 8. All measured values were significantly less than $0.0^{\circ} \mathrm{C}$ except at depths of 190 and $200 \mathrm{~m}$ in hole 14.3 T 1975 where pressure-melting temperatures were recorded. In all cases temperatures increased with depth and temperature gradients generally decreased with depth. The experimentally determined presence of a finite thickness of basal temperate ice supports thermal instability as the governing mechanism of surge behavior for this section of the ice cap.

Since drilling activities were carried on until the last days of the scheduled field season in an attempt to obtain as much of the desired coverage as feasible, it was not possible to collect sufficient cooling-curve data for a detailed analysis of the cooling-curve characteristics. The data which were gathered (by D. F. Classen and R. L. Hooke) are presented in Table III. Final measurements were made from $4 \mathrm{I}$ to $62 \mathrm{~d}$ after placement of the particular thermistors thereby allowing a generous dissipation time for the thermal disturbance introduced by drilling. Pressures due to ice overburden at the depths encountered were not believed to effect the thermistor characteristics or readings significantly (personal communication from A. E. Beck in 1975).

Figure 6 is the temperature-depth profile at $14.3 \mathrm{~T}$ 1975. The temperature increases with depth while the temperature gradient decreases with depth until $180 \mathrm{~m}$, where it undergoes a slight change in curvature and then, between 190 and $200 \mathrm{~m}$, becomes nearly vertical indicating the pressure-melting isotherm has been encountered.

Since it was not expected that such a depth would be attained with the drilling equipment, and since thermistor spacing was selected on the basis of previous experience, temperature coverage was regrettably not obtained for the upper section of the profile.

The pressure-melting temperature at depth $T_{z}$ was calculated using the equation for hydrostatic pressure in a fluid at rest which can be applied approximately in a crystalline solid

$$
T_{z}=G\left(P_{\mathrm{I}}-P_{0}\right)=G \rho g z \cos \alpha,
$$

where $P_{\mathrm{I}}$ is the pressure at depth $z, P_{0}$ the surface pressure, $\rho$ the density, $g$ the acceleration due to gravity, $\alpha$ the surface slope, and $z$ the depth from the surface. A value of $0.916 \mathrm{Mg} / \mathrm{m}^{3}$ was used for the density of ice, $980.665 \mathrm{~cm} / \mathrm{s}^{2}$ for $g$, and I oI $3.25 \mathrm{mbar}$ for a standard atmosphere $P_{0}$. The change of equilibrium temperature with pressure is a constant, $G$, given by $0.00743 \mathrm{deg} / \mathrm{bar}$. The pressure melting point at $190 \mathrm{~m}$ is thus $-0.133^{\circ} \mathrm{C}$ and at $200 \mathrm{~m}$ is 
Table III Gooling Gurve data

\begin{tabular}{|c|c|c|c|c|c|c|}
\hline \multirow[b]{2}{*}{$\begin{array}{c}\text { Depth } \\
\mathrm{m}\end{array}$} & \multicolumn{2}{|l|}{ Thermistor } & \multicolumn{2}{|l|}{ 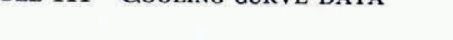 } & \multirow[b]{2}{*}{ Temperature } & \multirow[b]{2}{*}{ Temperature } \\
\hline & No & Temperature & Temperature & Temperature & & \\
\hline Location & I. 43 T I975 & $\underset{{ }^{\circ} \mathrm{C}}{\text { I9 }}{ }^{\text {May }}$ & $23 \underset{{ }^{\circ} \mathrm{C}}{\text { May }} \mathbf{I 9 7 5}$ & $25 \underset{{ }^{\circ} \mathrm{C}}{\text { May }} \mathrm{I} 975$ & $27 \underset{{ }^{\circ} \mathrm{C}}{\text { May }} 1975$ & ${ }^{2}$ July I 975 \\
\hline 140 & $1-13$ & $-0.4 \mathrm{I} \pm 002[3]$ & $-1.20[7]$ & $-\mathbf{1} \cdot 32[9]$ & $-1.37[\mathrm{Ir}]$ & $-1.50[47]$ \\
\hline 150 & $\mathrm{I}-\mathrm{I} 2$ & $-0.23 \pm 0$ or & $-0.5^{2}$ & -0.91 & -1.02 & -1.16 \\
\hline 160 & I-I I & $-0.18 \pm 0.01$ & -0.34 & -0.34 & -0.48 & -0.90 \\
\hline 170 & $I-10$ & $-0.14 \pm 0.02[2]$ & & -o.18 [8] & $-0.22[10]$ & $-0.66[46]$ \\
\hline 180 & I-Og & $-0.18 \pm 0.01$ & & -0.20 & $-0.2 \mathrm{I}$ & -0.23 \\
\hline I90 & $\mathrm{I}-\mathrm{0} 8$ & $-0.10 \pm 0.04$ & & -O. I I & -0.14 & -0.13 \\
\hline 200 & $\mathrm{I}-07$ & $-0.12 \pm 002$ & & - 013 & -0.17 & -0.13 \\
\hline Location & I9.5 T 1975 & 20 May 1975 & 25 May 1975 & 27 May 1975 & 2 July I975 & \\
\hline 10 & $0-4$ & $-9.26 \pm 0.02[\mathrm{r} 9]$ & $-9.28[24]$ & $-9 \cdot 34[26]$ & $-9.95[62]$ & \\
\hline 20 & $0-3$ & $-7.20 \pm 0.02$ & -7.19 & -7.20 & $-7 \cdot 3^{2}$ & \\
\hline 30 & $0-2$ & $-5.91 \pm 0.03[18]$ & $-5.95[23]$ & $-5.95[25]$ & $-6.06[6 \mathrm{I}]$ & \\
\hline 40 & $0-1$ & $-5.02 \pm 0.03$ & -5.06 & -5.07 & -5.13 & \\
\hline 17 & $0-10$ & $\begin{array}{c}2 \text { I May } 1975 \\
\pm 0.03\end{array}$ & $\begin{array}{l}25 \text { May } 1975 \\
-7.7 \text { I }[25]\end{array}$ & $\begin{array}{l}27 \text { May } 1975 \\
-7.73[27]\end{array}$ & $\begin{array}{l}\text { 2 July } 1975 \\
-7.91 \quad[63]\end{array}$ & \\
\hline Io & $0-2$ I & \pm 0.02 & $-9.19[19]$ & $-9.29[20]$ & $-9.95[57]$ & \\
\hline 20 & $0-20$ & \pm 0.02 & -7.19 & -7.19 & $-7 \cdot 3^{2}$ & \\
\hline 30 & O-I 9 & \pm 0.03 & $-5.9 \mathrm{I}$ & $-5 \cdot 9^{2}$ & -6.07 & \\
\hline 40 & $0-18$ & $-4.99 \pm 0.03\left[{ }_{15}\right]$ & -5.02 & -5.02 & -5.08 & \\
\hline 50 & $0-17$ & $-4.22 \pm 0.02$ & $-4.24[\mathrm{I} 7]$ & $-4.24[\mathrm{I} 9]$ & $-4.27\left[5^{6}\right]$ & \\
\hline 60 & $0-16$ & $-3.4^{8} \pm 0.02$ & $-3 \cdot 5^{1}$ & $-3 \cdot 5^{2}$ & -3.57 & \\
\hline 70 & O-I 5 & $-2.93 \pm 0.02[14]$ & -2.95 & -2.96 & -2.98 & \\
\hline 62 & $I-20$ & & $-3.04 \pm 0.01[4]$ & $-3.18[6]$ & $-3 \cdot 3^{8}\left[4^{2}\right]$ & \\
\hline $\begin{array}{l}72 \\
82\end{array}$ & $\begin{array}{l}1-19 \\
-198\end{array}$ & & $-2.41 \pm 0.01$ & $-2.5^{8}$ & -2.78 & \\
\hline $\begin{array}{l}82 \\
92\end{array}$ & I- 18 & & $-\mathrm{r} .88 \pm 0.02$ & $-2.1 \mathrm{I}$ & -2.32 & \\
\hline $\begin{array}{r}92 \\
102\end{array}$ & $\begin{array}{l}1-17 \\
1-16\end{array}$ & & $\begin{array}{l}-0.46 \pm 0.01 \\
-0.30+0.01\end{array}$ & $\begin{array}{l}-1.53 \\
-0.63\end{array}$ & $\begin{array}{l}-\mathrm{r} .86 \\
-\mathrm{I} .48\end{array}$ & \\
\hline 112 & $1-15$ & & $\begin{array}{l}-0.30 \pm 0.01 \\
-0.36 \pm 0.01[3]\end{array}$ & -0.03 [5] & $\begin{array}{l}-1.4^{8} \\
-1.12\left[4^{1}\right]\end{array}$ & \\
\hline 122 & $1-14$ & & $-0.22 \pm 0.02$ & -0.24 & -0.80 & \\
\hline Location & 24.55 T 1975 & 5 21 May I975 & 25 May 1975 & 27 May 1975 & 2 July 1975 & 3 July r 975 \\
\hline 28 & $I-6$ & $-4.57 \pm 0.09[14]$ & $-4.60[18]$ & $-4.6 \mathrm{I}[2 \mathrm{O}]$ & $-4.68[55]$ & $-4.68[57]$ \\
\hline 38 & $1-5$ & $-3.30 \pm 0.03$ & $-3 \cdot 34$ & $-3 \cdot 35$ & -3.40 & $-3.4 \mathrm{I}$ \\
\hline 48 & $I-4$ & $-2.46 \pm 0.02$ & $-2.4^{8}$ & $-2.5^{\circ}$ & -2.55 & -2.55 \\
\hline 58 & $1-3$ & $-1.80 \pm 0.06$ & -1.82 & $-\mathrm{I} .84$ & -1.88 & -1.88 \\
\hline 68 & $I-2$ & $-1.43 \pm 0.01$ & $-\mathrm{I} .47$ & $-1 \cdot 4^{8}$ & $-1 \cdot 5^{2}$ & $-1.5^{2}$ \\
\hline 78 & $I-I$ & $-1.07 \pm 0.04$ & -I.II & -1.12 & - I. I 7 & -I.I 7 \\
\hline 88 & $0-22$ & $-0.93 \pm 0.02$ & $-0.9^{8}$ & -1.00 & -1.04 & $-\mathrm{I} .04$ \\
\hline
\end{tabular}

The figures in square brackets are the lapse times in days.

$-0.140^{\circ} \mathrm{C}$. Both of these values lie within the range of experimental error of the measurements at these points (see Table II) and therefore it is concluded that the ice is at the pressure melting point from $190 \mathrm{~m}$ to $200 \mathrm{~m}$ depth and presumably isothermal to bedrock, where at $220 \mathrm{~m}$ its temperature would be - o. $54^{\circ} \mathrm{C}$.

The change in curvature of the temperature profile defines a zone approximately $10 \mathrm{~m}$ thick where sub-polar ice grades into ice at the pressure melting point which is probably thermally disturbed. This may be a memory from previous higher rates of movement and increased internal heating due to shear along the interface between the ice types. At any rate, it is an interesting feature and may be worthy of further investigation.

Figure 7 shows a highly convex-upward profile with the temperature increasing with depth and the temperature gradient decreasing with depth. The upper section of the curve comprises data from three separate thermistor cables all located within $\mathrm{I} \mathrm{m}$ of each other and with final measurements taken between 56 and $63 \mathrm{~d}$ after placement thereby ensuring equilibrium 


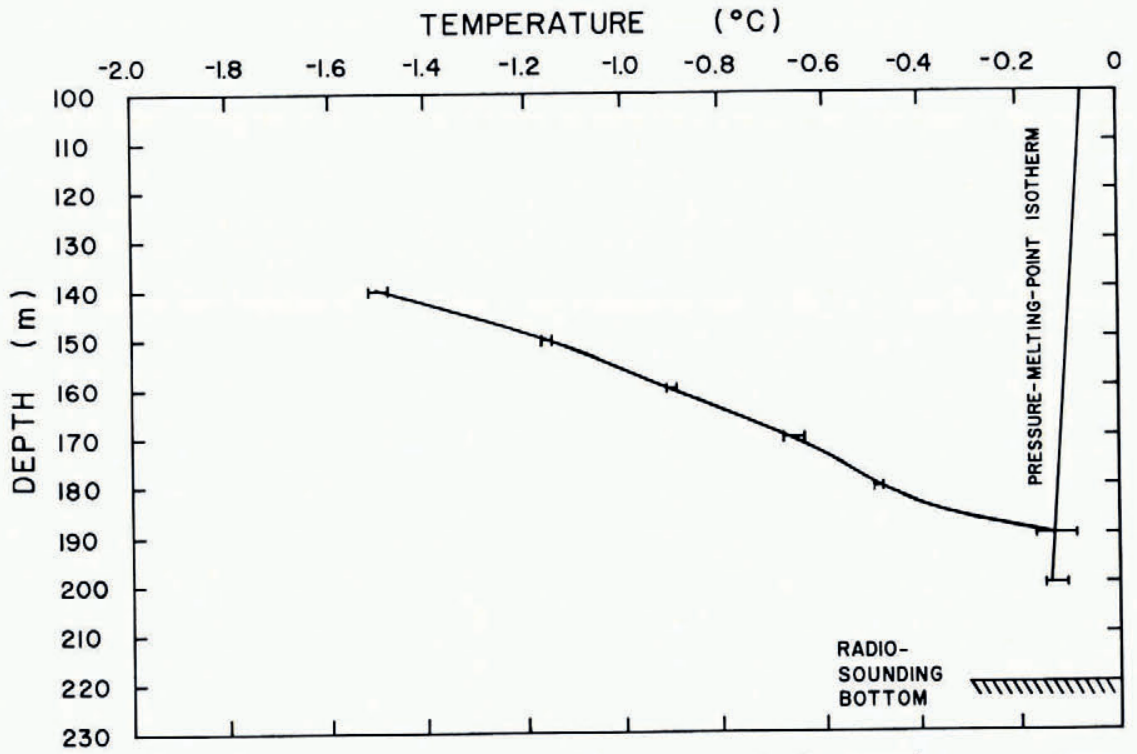

Fig. 6. Temperature profile at $14.3 \mathrm{~T} 1975$ on 2 July 1975 . Basal temperate ice is present from $190 \mathrm{~m}$ to $200 \mathrm{~m}$ depth and presumably to bedrock.

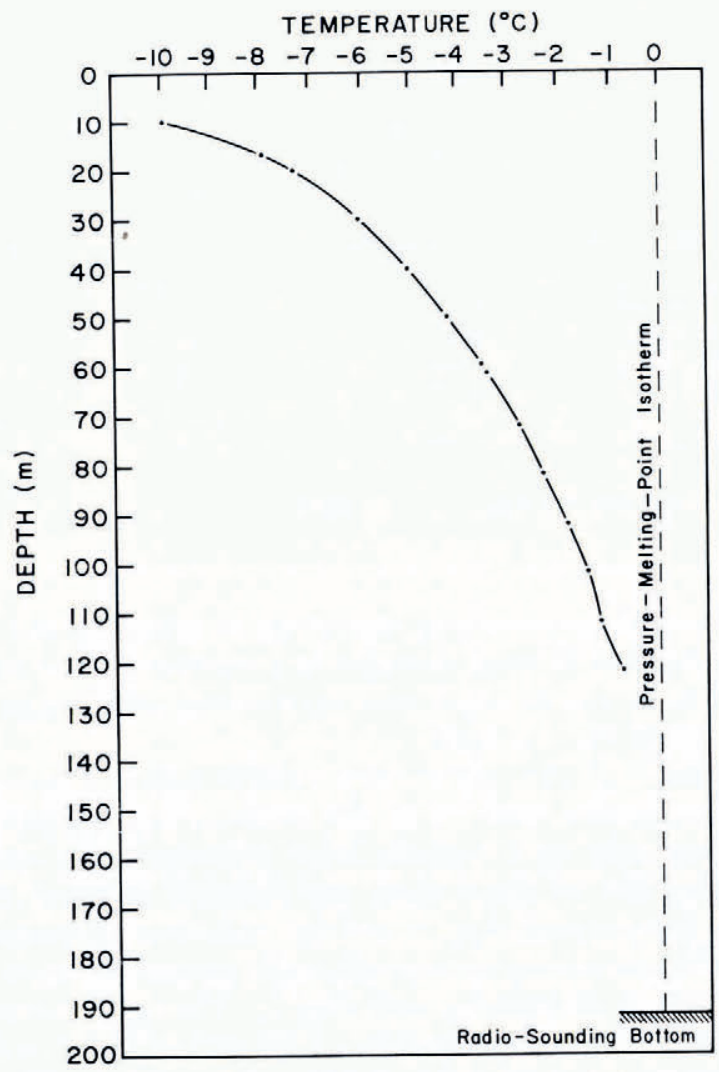

Fig. 7. Temperature profile at $19.5 \mathrm{~T} 1975$ on 2 Fuly 1975. 
At points where two thermistors were in near proximity, their temperature values agreed to within \pm o.or deg. The lower section of the curve represents data from the last thermistor cable placed during the season. The lower curve had not reached equilibrium at the time of final measurement $42 \mathrm{~d}$ after placement. This section of curve has been corrected to equilibrium values. A slight change in the curvature is apparent at the very end of the curve. It is believed that the temperature indicated at the last point may not be an equilibrium value since the probe apparently entered a debris-laden zone. The resulting decrease in drilling speed would produce a much larger hole and the greater thermal input would retard the reestablishment of equilibrium conditions. In addition, the debris particles in the ice would alter normal heat diffusion rates, a factor which greatly complicates analysis.

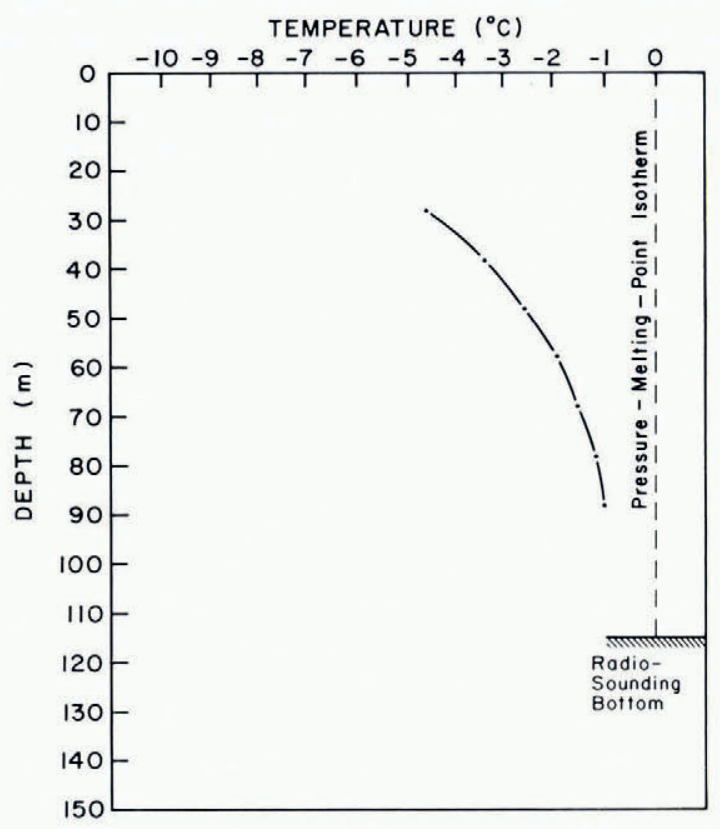

Fig. 8. Temperature profile at $24.55 \mathrm{~T}$ I975 on 3 July 1975 .

A linear extrapolation to bedrock based on the second and third lowest points would indicate a finite layer of basal temperate ice. An extrapolation based on the rate of decrease of the thermal gradient would suggest sub-freezing basal temperatures. Evidence from Figure 6 would lead to the possibility of an unexpected change in gradient as the profile nears the pressure-melting isotherm and therefore it is felt that a simplistic extrapolation cannot be conclusive for predicting basal ice conditions and therefore no interpretation is presently offered.

Figure 8 , at $24.55 \mathrm{~T}$ i 975 near the snout of the surge section, shows a profile similar to Figure 6 with a gradient of $0.14 \pm 0.006 \mathrm{deg} / \mathrm{m}$ between 78 and $88 \mathrm{~m}$. Final measurements were made $57 \mathrm{~d}$ after placement and are all equilibrium. A linear projection of the curve to bedrock ( $115 \mathrm{~m}$ ) places the basal temperature at $-0.69^{\circ} \mathrm{C}$. Since the gradient should continue to decrease with depth, this estimate would be slightly warm. The margin, then, appears to be frozen to the bedrock, though at a temperature much warmer than previous theoretical calculations (Holdsworth, 1973[a]) estimated. 


\section{Discussion}

\section{Temperate ice layer}

The thermal regime of the Barnes Ice Cap surge zone suggested by the three temperature profiles is strikingly similar to those of the Rusty and Trapridge Glaciers in the Yukon (Classen and Clarke, 1971, 1972; Jarvis and Clarke, 1975) but with an experimentally determined basal layer of temperate ice of substantial thickness. The snout, frozen to bedrock, would appear to act as an ice dam causing the build-up of an ice reservoir in the receiving area upglacier from the snout. Some evidence of this may be seen in the surface profile between I4.3 T 1975 and 24.55 T 1975 in Figure 3. These results would support a thermal instability mechanism such as presented by Robin (1955, I969) or Hoffmann and Clarke (1973) as the explanation for, and the governing mechanism of, the surge behavior.

The temperature profiles of all three holes indicate that the basal gradient is very small and essentially zero in the case of hole $14.3 \mathrm{~T}$ i 975 where the pressure-melting isotherm is intersected. The situation would imply non-steady-state conditions and would be thermally unstable since the gradients would be able to transmit upwards little or none of the geothermal heat, frictional heat of sliding, or latent heat of refreezing water. In addition, vertical ice velocities with the ice increasing in thickness in the relatively recent past are suggested. This would mean that the observed temperature gradients would have to be accounted for by mean annual surface temperature, viscous heat generation, and latent-heat exchange at the boundary of the temperate and cold ice zones except where the pressure melting point exists only along the ice-rock contact, in which event some of the geothermal heat and latent heat of refreezing would flow into the ice. Where ice is frozen to bedrock, a local zone of thermal stability would exist with departures from steady-state being explained primarily by recent ice motion.

This problem is discussed by Lliboutry (1966) and further elaborated upon in more general terms by Jarvis and Clarke (1975) where it is presented that these conditions have long been thought feasible for sufficiently thick ice bodies.

Prior to completion of surface-movement survey results for the ss flow line, no correlation between areas of basal temperate or cold ice and surface strain-rate data can be given. One would expect active motion and extension above the layer of temperate ice with a gradual grading to compression and possible stagnation over the cold basal zone. In the area where the temperate layer thins so that only the base is at the pressure melting point, a simple model would lead to the expectation of a positive vertical flow rate reflecting the damming effect of the cold basal margin, the build-up of an ice reservoir, and the addition of ice at the base from refreezing of water melted in the central region.

\section{Geothermal heat flow}

An estimate of geothermal heat flow was determined using data from 24.55 T 1975 where glacier bedrock was approached and no basal temperate ice was present. This value corrected for the effects of climatic variation, does not indicate an anomalously large heat flow but, rather, one slightly below world average as would be expected for this region. Corrections for topographic distortions were not thought to be necessary.

The heat flux $Q$ was calculated using the relationship for uniform heat flow through a slab, $Q=(k / d)\left(t_{1}-t_{2}\right)$ where $k$ is the thermal conductivity, $d$ the distance between the bottom two thermistors, $t_{\mathrm{I}}$ the bottom temperature, $t_{2}$ the temperature a distance $d$ from the bottom. The thermal conductivity of ice varies with temperature and density. For the geothermal estimates based on the Barnes Ice Cap data, values of $k$ were determined from the formula $k=2.24\left(\mathrm{I}-4.8 \times \mathrm{IO}^{-3} \theta\right) \mathrm{W} / \mathrm{m}$ deg where $\theta$ is the average ice Celsius temperature between $t_{1}$ and $t_{2}$ (Pounder, 1965). The conductivity was not adjusted for density variations since such variations were thought to be slight. 
A method for calculating climatic corrections to heat-flow measurements was presented by Crain (1969) who has shown that the small details of climatic variations have little ultimate effect on the heat-flow correction. The critical factors are the transition times between glacial and interglacial periods and the difference in mean annual temperature between these periods. The most recent deglaciation alone accounts for $70 \%$ of the correction.

Calculations based on the near-surface approximation for depths less than $150 \mathrm{~m}$ give corrections of $+22 \mathrm{~mW} / \mathrm{m}^{2}$ for the most recent deglaciation (Io ooo years ago) and -9 $\mathrm{mW} / \mathrm{m}^{2}$ for the previous glaciation (6o ooo years ago) assuming a temperature increment of Io.o deg. The total correction is $+13 \mathrm{~mW} / \mathrm{m}^{2}$. The calculated value of $Q$ for $24.55 \mathrm{~T} 1975$ is $29 \mathrm{~mW} / \mathrm{m}^{2}$. Corrected for climatic variations this becomes $42 \mathrm{~mW} / \mathrm{m}^{2}$.

The value for heat flow should be viewed with a certain amount of caution since it is possible that the ice in this region may not be old enough to have been affected by ice-age changes in climate. In addition, no account has been taken of vertical ice velocities in the region of the calculation or of the complex ice history resulting from the surge.

Rao and Jessop (1975) discussed the low heat-flow values generally associated with Pre-Cambrian shield areas and conclude that the mean heat-flow values in such regions are much lower than those of all continental values or the world-wide average. Twenty shield values analysed indicate a range of $2 \mathrm{I}$ to $55 \mathrm{~mW} / \mathrm{m}^{2}$ with a mean value of $39 \mathrm{~mW} / \mathrm{m}^{2}$. The world-wide average heat flow is about $63 \mathrm{~mW} / \mathrm{m}^{2}$ (Lee and Uyeda, i 965 ).

Measurements of geothermal heat flux in Baffin Bay and the Labrador Sea (Pye and Hyndman, 1972) indicate mean values of 57 and $56 \mathrm{~mW} / \mathrm{m}^{2}$ respectively, with the heat flows in the center of Baffin Bay being slightly higher than the heat flows towards the sides. The lack of a pronounced thermal anomaly in the region suggests little or no sea-floor spreading and an extinct ridge zone.

Sass and others (1972) give values of 38 and $42 \mathrm{~mW} / \mathrm{m}^{2}$ for two sites in the Pre-Cambrian shield of south Greenland.

Any depression of isotherms along the eastern margin of Baffin Island which may have resulted from earlier plate subduction has as a result nearly recovered and it is therefore safe to assume that a reasonable regional value for heat flow below central Baffin Island would be in the vicinity of $46 \pm 4^{2} \mathrm{~mW} / \mathrm{m}^{2}$ which lies mid-way along the gradation of values for the shield and extinct ridge regions and close to the Greenland values.

Holdsworth (I973[a]) used the Jenssen and Radok (1963) model for his calculations of basal temperatures and a geothermal flux of $67 \mathrm{~mW} / \mathrm{m}^{2}$. Hooke (1976) finds that a figure of $59 \mathrm{~mW} / \mathrm{m}^{2}$ is required with the Budd and others (I97I) simple column-model equation to arrive at basal melting temperatures and that a value of $40 \mathrm{~mW} / \mathrm{m}^{2}$ fails to produce these conditions. Should a regional heat-flow value of $46 \mathrm{~mW} / \mathrm{m}^{2}$ be adopted as recommended and the remaining known parameters for this section of the ice cap be taken into account, it would seem that a fairly opportune situation exists in terms of a field case for the improvement of these mathematical models.

\section{Acknowledgements}

This research was financed under Department of Supply and Services contract No. $\mathrm{oSS}_{4}-\mathrm{O}_{3} 6_{3}$ awarded to University of Victoria. Support from Environment Canada is gratefully acknowledged. The author wishes to thank G. Holdsworth, G. K. C. Clarke, R. L. Hooke, J. M. Dewey, H. W. Dosso, W. Barss and R. Horita for helpful discussions. He also wishes to express thanks to G. Holdsworth, A. Gour, B. Kronberger, and R. Flanders for generous assistance in the field and to R. L. Hooke for measuring final temperatures.

MS. received 26 January 1976 and in revised form 22 October 1976 


\section{REFERENCES}

Baird, P. D. 1952. The glaciological studies of the Baffin Island Expedition, 1950. Part I: method of nourishment of the Barnes Ice Cap. Fournal of Glaciology, Vol. 2, No. I I, p. 2-9.

Barnett, D. M., and Holdsworth, G. 1974. Origin, morphology, and chronology of sublacustrine moraines, Generator Lake, Baffin Island, Northwest Territories, Canada. Canadian Journal of Earth Sciences, Vol. I I, No. 3 , p. $380-408$.

Barnett, D. M., and others. 1970. Generator Lake, Baffin Island, [by] D. M. Barnett, D. L. Forbes, J. K. Whytock. Canadian Oceanographic Data Centre, 1970 Data Record Series No. I, p. 7-27.

Budd, W. F., and others. I 97 I. Derived physical characteristics of the Antarctic ice sheet. Mark I, by W. F. Budd, D. Jenssen and U. Radok. Melbourne, University of Melbourne, Meteorology Dept. (University of Melbourne, Meteorology Dept., Publication No. 18.)

Classen, D. F. Unpublished. Thermal drilling and deep ice-temperature measurements on the Fox Glacier, Yukon. [M.Sc. thesis, University of British Columbia, 1970.]

Classen, D. F., and Clarke, G. K. G. 1971. Basal hot spot on a surge type glacier. Nature, Vol. 229, No. 5285 , p. $48 \mathrm{I}-83$.

Glassen, D. F., and Clarke, G. K. C. 1972. Thermal drilling and ice-temperature measurements in the Rusty Glacier. (In Bushnell, V. G., and Ragle, R. H., ed. Icefield Ranges Research Project. Scientific results. Vol. 3. New York, American Geographical Society; Montreal, Arctic Institute of North America, p. 103-16.)

Clough, J., and Løken, O. H. Ig68. Radio-echo soundings on the Barnes Ice Cap. (In North-central Baffin Island field report 1967 . Ottawa, Dept. of Energy, Mines and Resources. Inland Waters Branch, p. 87-96. (Report Series No. 2.))

Crain, I. K. 1969. A simple method of calculating climatic corrections to heat flow measurements. Canadian Fournal of Earth Sciences, Vol. 6, No. 3, p. 499-502.

Goldthwait, R. P. r951. Development of end moraines in east-central Baffin Island. Fournal of Geology, Vol. 59, No. 6 , p. $567-77$.

Hoffmann, J. W., and Clarke, G. K. C. 1973. Periodic temperature instabilities in sub-polar glaciers. (In [International Hydrological Decade.] The role of snow and ice in hydrology. Proceedings of the Banff symposia, September 1972. Paris, UNESCO; Geneva, WMO; Budapest, IAHS, Vol. I, p. 445-53.)

Holdsworth, G. I973[a]. Evidence of a surge on Barnes Ice Cap, Baffin Island. Canadian Fournal of Earth Sciences, Vol. ro, No. ro, p. 1565-74.

Holdsworth, G. I973[b]. Ice calving into the proglacial Generator Lake, Baffin Island, N.W.T., Canada. Journal of Glaciology, Vol. 12, No. 65, p. 235-50.

Hooke, R. L. 1973[a]. Flow near the margin of the Barnes Ice Cap, and the development of ice-cored moraines. Geological Society of America. Bulletin, Vol. 84, No. 12, p. 3929-48.

Hooke, R. L. 1973[b]. Structure and flow in the margin of the Barnes Ice Cap, Baffin Island, N.W.T., Canada. Journal of Glaciology, Vol. 12, No. 66, p. 423-38.

Hooke, R. L. 1976 . Pleistocene ice at the base of the Barnes Ice Cap, Baffin Island, N.W.T., Canada. Journal of Glaciology, Vol. 17, No. 75, p. 49-59.

Jarvis, G. T. Unpublished. Thermal studies related to surging glaciers. [M.Sc. thesis, University of British Columbia, 1973.]

Jarvis, G. T., and Clarke, G. K. C. 1975. The thermal regime of Trapridge Glacier and its relevance to glacier surging. Journal of Glaciology, Vol. 14, No. 71, p. 235-50.

Jenssen, D., and Radok, U. I963. Heat conduction in thinning ice sheets. Fournal of Glaciology, Vol. 4, No. 34, p. $387-97$.

Jones, S. J. I972. Radio depth-sounding on Meighen and Barnes ice caps, Arctic Canada. Ottawa, Environment Canada. Water Resources Branch. Inland Waters Directorate. (Scientific Series No. 25.)

Lee, W. H. K., and Uyeda, S. I965. Review of heat flow data. (In Lee, W. H. K., ed. Terrestrial heat flow. Washington, D.C., American Geophysical Union, p. 87-19o. (Geophysical Monograph Series, No. 8.))

Littlewood, C. A. 1952. Gravity measurements on the Barnes Icecap, Baffin Island. Arctic, Vol. 5, No. 2, p. II 8-24.

Lliboutry, L. A. 1966. Bottom temperatures and basal low-velocity layer in an ice sheet. Fournal of Geophysical Research, Vol. 71, No. 10, p. 2535-43; No. 24, p. 6152.

Løken, O. H. 1969. Evidence of surges on the Barnes Ice Cap, Baffin Island. Canadian Journal of Earth Sciences, Vol. 6, No. 4, Pt. 2, p. 899-9or.

Løken, O. H., and Andrews, J. T. 1966. Glaciology and chronology of fluctuations of the ice margin at the south end of the Barnes Ice Cap, Baffin Island, N.W.T. Geographical Bulletin (Ottawa), Vol. 8, No. 4, p. 34 I-59.

Loken, O. H., and Sagar, R. B. r968. Mass balance observations on the Barnes Ice Cap, Baffin Island, Canada. Union de Géodésie et Géophysique Internationale. Association Internationale d'Hydrologie Scientifique. Assemblée générale de Berne, 25 sept.-7 oct. 1967. [Commission de Neiges et Glaces.] Rapports et discussions, p. 282-91. (Publication No. 79 de l'Association Internationale d'Hydrologie Scientifique.)

Loken, O. H., and others. 1968. Surface movement and strain net measurements-Barnes Ice Cap, by O. H. Løken, A. Geiger and P. Langlais. (In North-central Baffin Island field report Ig67. Ottawa, Dept. of Energy, Mines and Resources. Inland Waters Branch, p. 97-102. (Report Series No. 2.))

Orvig, S. 1953. The glaciological studies of the Baffin Island Expedition, 1950. Part V: on the variation of the shear stress on the bed of an ice cap. Fournal of Glaciology, Vol. 2, No. 14, p. 242-48.

Pounder, E. R. 1965 . The physics of ice. Oxford, etc., Pergamon Press. (The Commonwealth and International Library. Geophysics Division.) 
Pye, G. D., and Hyndman, R. D. 1972. Heat-flow measurements in Baffin Bay and the Labrador Sea. Journal of Geophysical Research, Vol. 77, No. 5, p. 938-44.

Rao, R. U. M., and Jessop, A. M. 1975. A comparison of the thermal characters of shields. Canadian Fournal of Earth Sciences, Vol. 12, No. 3, p. 347-6o.

Robin, G. de Q. 1955. Ice movement and temperature distribution in glaciers and ice sheets. Journal of Glaciology, Vol. 2, No. 18, p. 523-32.

Robin, G. de Q. 1969. Initiation of glacier surges. Canadian Fournal of Earth Sciences, Vol. 6, No. 4, Pt. 2, p. 919-28.

Sapoff, M., and Oppenheim, R. M. 1963. Theory and application of self-heated thermistors. Proceedings of the IEEE, Vol. 51, No. 10, p. 1292-1305.

Sass, J. H., and others. 1972 . Heat flow and surface radioactivity at two sites in south Greenland, by J. H. Sass, B. L. Nielsen, H. A. Wollenberg and R. J. Munroe. Journal of Geophysical Research, Vol. 77, No. 32, p. 6435-44. Ward, W. H. 1952[a]. The glaciological studies of the Baffin Island Expedition, 1950. Part II: the physics of deglaciation in central Baffin Island. Fournal of Glaciology, Vol. 2, No. I I, p. 9-22.

Ward, W. H. ${ }^{1} 95^{2}[\mathrm{~b}]$. The glaciological studies of the Baffin Island Expedition, 1950. Part III : equipment and techniques. Fournal of Glaciology, Vol. 2, No. 12, p. 1 I 5-2 I.

Ward, W. H., and Orvig, S. r953. The glaciological studies of the Baffin Island Expedition, I950. Part IV: the heat exchange at the surface of the Barnes Ice Cap during the ablation period. Fournal of Glaciology, Vol. 2, No. 13 , p. $158-68$. 